\title{
Penilaian Kondisi Eksisting Tata Kelola Teknologi Informasi Pada Perangkat Daerah Menggunakan Cobit 5
}

\author{
Aisyah Nuraeni \\ Fakultas Teknik \\ Program Studi Informatika \\ Universitas Langlangbuana \\ aisyahnuraeni@unla.ac.id
}

\begin{abstract}
Abstrak - Penilaian Tata Kelola Teknologi Informasi adalah mengukur kondisi nyata penatakelolaan teknologi informasi pada sebuah organisasi. Pengukuran ini bertujuan untuk meningkatkan ketepatan dalam melakukan perbaikan kondisi tata kelola TI sehingga investasi TI yang dikeluarkan selaras dengan manfaat yang diperoleh dalam pemenuhan tujuan organisasi. Pada Penelitian ini organisasi yang dimaksud adalah perangkat daerah pemerintah kota. Pemerintah Kota memiliki kompleksitas masalah dalam mencapai tujuannya, sehingga target penilaian di breakdown kepada perangkat daerah selaku tombak operasional Kota. Penilaian Tata kelola TI ini menggunakan COBIT 5 yaitu PAM dengan prioritas proses yang terpilih adalah berkenaan dengan pengelolaan anggaran, sumber daya manusia, pendefinisian kebutuhan, aset, operasi, dan evaluasi. Rata-rata hasil penilaian berada pada level 1 .
\end{abstract}

Kata kunci - Penilaian, Tata Kelola TI, Perangkat Daerah, COBIT 5

\section{PENDAHULUAN}

\subsection{Latar Belakang}

Penerapan Tata Kelola Teknologi Informasi sangat diperlukan. Hal ini berkaitan dengan pengoptimalan nilai dari pengembangan investasi, penggunaan teknologi informasi, dan melindungi informasi[1]. Karena kebutuhan akan informasi memaksa Pemerintah Kota melakukan investasi besar dalam pemenuhan sumber daya informasinya sehingga Tata Kelola Teknologi Informasi merupakan salah satu tanggung jawab penting pengelola TIK Pemerintahan Kota disamping tugas lainnya dalam mengelola sumber daya dan menangani masalah yang berkaitan dengan teknologi. Dengan Penilaian Tata Kelola TIK diharapkan dapat melakukan efisiensi proses penilaian dan menghasilkan potret kondisi tingkat kematangan TIK, hal ini penting dalam mengetahui kesesuaian penggunaan teknologi dengan tujuan bisnis organisasi [2]
Penilaian (Asessment) Tata Kelola Teknologi Informasi di Lingkungan Pemerintahan Kota sangat diperlukan untuk mengetahui dan memotret kondisi pengelolaan TI saat ini, sehingga dapat menentukan strategi ataupun solusi untuk mencapai target yang diinginkan[3]. Idealnya dengan menerapkan dasar dasar Tata Kelola TI yang baik tentunya akan mendukung pencapaian tujuan Pemerintah Kota dengan meninjau pemanfaatan Teknologi Informasi, dan memastikan investasi yang dikeluarkan sebanding dengan manfaatnya.[4]

Dalam melakukan penilaian Tata Teknologi Informasi diperlukan alat bantu yang relevan, praktek-praktek yang baik dan standar perlu disesuaikan untuk memenuhi kebutuhan spesifik dari lingkungan spesifik organisasi. COBIT 5 adalah kerangka best practices yang lengkap, karena semua proses pada standar atau framework lain terwakili[5].

COBIT 5 menggunakan PAM (Process Assessment Model) sebagai model penilaian yaitu didasarkan pada standar ISO / IEC 15504 untuk melakukan penilaian proses. Penilaian proses didasarkan pada model dua dimensi yang mengandung dimensi proses dan dimensi kemampuan. Dimensi proses disediakan oleh Model Referensi Proses COBIT 5 yang mendefinisikan serangkaian proses yang dicirikan oleh pernyataan tujuan proses dan hasil proses. Dimensi kemampuan terdiri dari kerangka pengukuran yang terdiri dari enam tingkat kemampuan proses dan atribut proses yang terkait[6].

Penilaian Tata Kelola Teknologi Informasi dilakukan dengan kunjungan langsung, yaitu Perangkat Daerah ditinjau secara langsung untuk mengetahui kondisi nyata pengelolaan TIK berbasis bukti di lapangan. Dengan hal tersebut maka akan menghasilkan informasi yang relevan dan dapat digunakan sebagai Referensi Dasar dan Alat Kontrol pelaksanaan dan pengembangan TIK di lingkungan Pemerintahan Kota pada era E-Government. 


\subsection{Rumusan Masalah}

1. Bagaimana menilai kondisi eksisting tingkat kematangan tata kelola teknologi informasi pada perangkat daerah

2. Berada pada level berapa nilai kematangan tata kelola teknologi informasi pada perangkat daerah Tata Kelola Teknologi Informasi sangat diperlukan.

\section{METODE}

\subsection{Tahapan Penelitian}

Tahapan penelitian yang dilakukan adalah sebagai berikut:

1. Studi Literature: Meninjau dokumen terkait tata kelola TI dari berbagai sumber, baik eskternal maupun internal.

2. Pemilihan Proses pada COBIT 5: Pemilihan Proses Pada Cobit 5 diawali dengan melakukan pemetaan tujuan organisasi dengan Tujuan COBIT 5, kemudian menyelaraskan dengan Tujuan TI dan menyesuaikan dengan Proses TI.

3. Umpan balik: Untuk mengetahui efektifitas dan beban kuisioner penilaian dilakukan umpan balik, Diskusi dengan Operator Perangkat Daerah bertujuan guna mengumpulkan berbagai informasi secara detail sehingga dapat dilakukan penyesuaian.

4. Penyesuaian: Penyesuaian dilakukan dengan cara melakukan pemetaan dokumen pemerintahan dengan dokumen COBIT 5 dan perbaikan aplikasi. Acuan penyesuaian pada pemetaan berdasarkan diskusi dengan pihak-pihak terkait (sampling perangkat Daerah).

5. Sosialisasi: Setelah penyesuaian dilakukan, selanjutnya adalah sosialisasi pengisian data untuk menentukan nilai kematangan Tata kelola TI kepada Perangkat Daerah sebagai target pengisi data

6. Pengisian Data: Perangkat Derah mengisi data melalui form penilaian mandiri, kemudian untuk memeriksa isian dilakukan kunjungan lapangan oleh peneliti.

7. Penilaian Kondisi Tata kelola TI: Melakukan penilaian kapabilitas tata kelola TI pada perangkat daerah dengan tujuan dapat dilakukan langkah selanjutnya yatu analisis gap antara kondisi ideal dan eksisting untuk membuat roadmap pemenuhan tujuan yang lebih akurat.

\subsection{Cascading Tujuan Organisasi ke Proses TI pada COBIT 5}

Organisasi dibuat untuk memenuhi kebutuhan dari stakeholder. Tata kelola adalah tentang bernegosiasi dan memutuskan di antara kepentingan nilai pemangku kepentingan yang berbeda. Sebagai akibatnya, sistem tata kelola harus mempertimbangkan semua pemangku kepentingan ketika mengambil keputusan penilaian manfaat, risiko dan sumber daya.

Rangkaian sasaran COBIT 5 adalah mekanisme untuk menerjemahkan kebutuhan pemangku kepentingan menjadi sasaran perusahaan yang spesifik, dapat ditindaklanjuti dan disesuaikan, sasaran terkait TI, dan sasaran pemungkin

Adapun dokumen yang digunakan dalam penentuan tujuan organisasi adalah RPJMD (Rencana Pembangunan Jangka Menengah Daerah) dan Master Plan TI Kota sedangkan dalam pemilihan proses mempertimbangkan aturan dan dokumen terkait evaluasi tata kelola TIK seperti Peraturan Wali Kota tentang Kebijakan Tata Kelola Teknologi

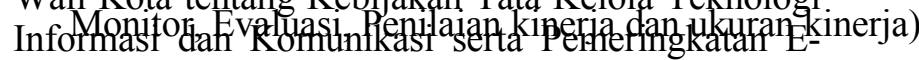
Government Indonesia.

Tahapan mengcasecade tujuan organisasi sampai dengan enabler goals (proses terkait TI) dapat dilihat pada gambar berikut[5].

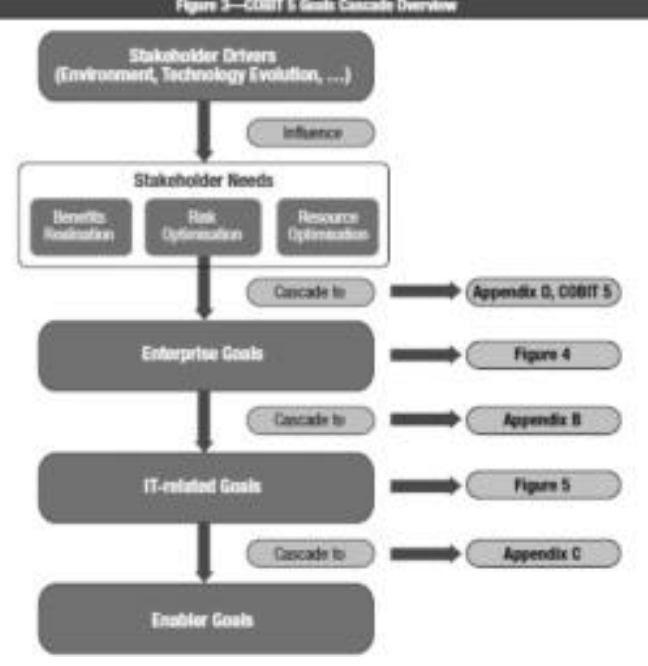

Gambar 1. Overview Goals Cascade

\subsection{Process Assessment Model (PAM)}

Model penilaian proses pada COBIT 5 menggunakan framework yang berbeda dengan COBIT 4.1. Skala ini merepresentasikan peningkatan kapabilitas proses yang diimplementasikan, dari proses yang belum mencapai tujuan sampai roses yang memenuhi tujuan bisnis saat ini dan yang akan datang [6]. 


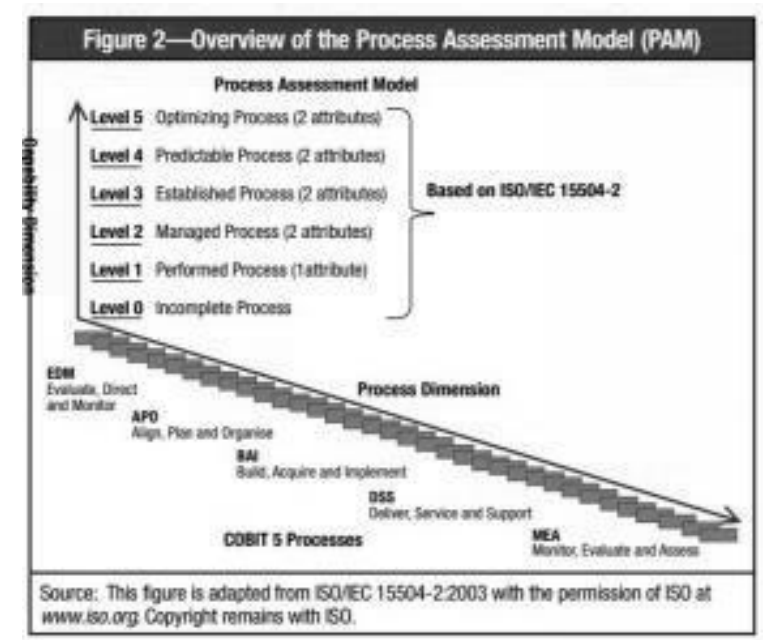

Gambar 2. Overview Process Assessment Model (PAM)

Kapabilitas proses terdiri dari 6 skala poin yang dimulai dari 0 sampai 5 seperti pada tabel di bawah.

\section{TABEL $1 . \quad$ Skala Kapabilitas}

\begin{tabular}{|l|l|}
\hline Skala & Keterangan \\
\hline $\begin{array}{l}\text { Level 0 } \\
\text { Incomplete } \\
\text { process }\end{array}$ & $\begin{array}{l}\text { Proses tidak diimplementasikan atau gagal } \\
\text { mencapai tujuan proses. Pada level ini, ada } \\
\text { sedikit atau bahkan tidak ada bukti akan } \\
\text { pencapaian tujuan proses. }\end{array}$ \\
\hline $\begin{array}{l}\text { Level 1 } \\
\text { Perfomed process }\end{array}$ & $\begin{array}{l}\text { Proses yang diimplementasikan mencapai } \\
\text { tujuan prosesnya }\end{array}$ \\
\hline $\begin{array}{l}\text { Level } 2 \\
\text { Managed process }\end{array}$ & $\begin{array}{l}\text { Proses yang diimplementasikan, dikelola } \\
\text { (direncanakan dimonitor dan disesuaikan) } \\
\text { dan hasilnya ditetapkan, dikontrol dan } \\
\text { dipelihara. }\end{array}$ \\
\hline $\begin{array}{l}\text { Level 3 } \\
\text { Established } \\
\text { process }\end{array}$ & $\begin{array}{l}\text { Proses yang dikelola, diimplementasikan } \\
\text { dengan menggunakan proses } \\
\text { ditetapkan, yang mampu mencapai hasil } \\
\text { proses }\end{array}$ \\
\hline $\begin{array}{l}\text { Level 4 } \\
\text { Predictable } \\
\text { process }\end{array}$ & $\begin{array}{l}\text { Proses yang ditetapkan, dioperasikan } \\
\text { dengan batasan yang ditetapkan untuk } \\
\text { mencapai hasil proses. }\end{array}$ \\
\hline $\begin{array}{l}\text { Level 5 } \\
\text { Optimizing } \\
\text { process }\end{array}$ & $\begin{array}{l}\text { Proses yang dapat diprediksi ditingkatkan } \\
\text { secara kontinu untuk memenuhi tujuan } \\
\text { bisnis saat ini dan masa yang akan datang. }\end{array}$ \\
\hline
\end{tabular}

Pada penilaian kapabilitas tata kelola TI menurut PAM, untuk dapat naik ke level berikutnya harus bernilai Fully achieved $(\mathrm{F})$ yaitu mencapai $\geq 85 \%$.

\subsection{RACI}

RACI merupakan singkatan dari R (Responsible), A (Accountable), C (Consulted), dan I (Informed). Diagram RACI adalah bagian dari Responsibility Assignment Matrix (RAM), yaitu pemetaan antara sumberdaya dengan aktivitas dalam setiap prosedur. Setiap Proses umumnya memiliki RACI yang berbeda. Tabel berikut menjelaskan arti dari nilai pada diagram RACI[5].
TABEL 2. Arti dan Nilai RACI

\begin{tabular}{|l|l|}
\hline \multicolumn{1}{|c|}{ Nilai } & \multicolumn{1}{|c|}{ Arti } \\
\hline R (Responsible) & $\begin{array}{l}\text { bagian yang merupakan pihak pelaksana } \\
\text { yang harus bertanggung jawab melaksanakan } \\
\text { dan menyelesaikan aktivitas yang menjadi } \\
\text { tanggung jawabnya }\end{array}$ \\
\hline A (Accountable) & $\begin{array}{l}\text { bagian yang merupakan pihak yang harus } \\
\text { mengarahkan jalannya pelaksanaan aktivitas }\end{array}$ \\
\hline C(Consulted) & $\begin{array}{l}\text { bagian yang merupakan pihak yang akan } \\
\text { menjadi tempat konsultasi selama } \\
\text { pelaksanaan aktivitas }\end{array}$ \\
\hline I (Informed). & $\begin{array}{l}\text { bagian yang merupakan pihak yang diberikan } \\
\text { infromasi }\end{array}$ \\
\hline
\end{tabular}

Sedangkan rating setiap level harus mencapai nilai persentase berikut.

TABEL 3. Rating level

\begin{tabular}{|c|l|l|}
\hline Abbreviation & Description & \% Achieved \\
\hline N & Not achieved & 0 to $15 \%$ achievement \\
\hline P & $\begin{array}{l}\text { Partially } \\
\text { achieved }\end{array}$ & $\begin{array}{l}>15 \% \text { to } 50 \% \\
\text { achievement }\end{array}$ \\
\hline L & $\begin{array}{l}\text { Largely } \\
\text { achieved }\end{array}$ & $\begin{array}{l}>50 \% \text { to } 85 \% \\
\text { achievement }\end{array}$ \\
\hline F & $\begin{array}{l}\text { Fully } \\
\text { achieved }\end{array}$ & $\begin{array}{l}>85 \% \text { to } 100 \% \\
\text { achievement }\end{array}$ \\
\hline
\end{tabular}

Berikut adalah RACI pada setiap proses:

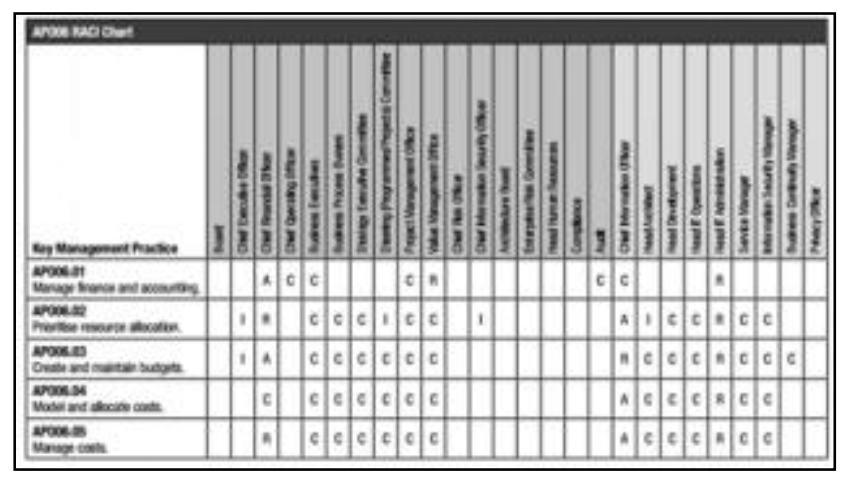

Gambar 3. RACI APO06

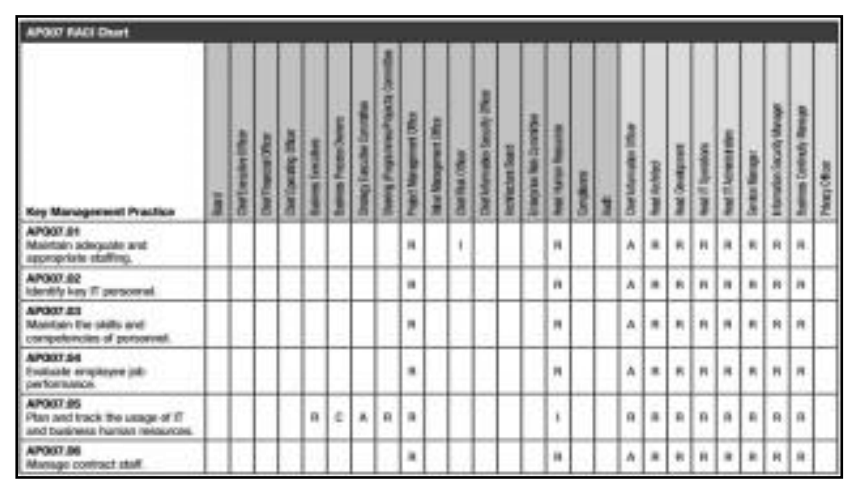

Gambar 4. RACI APO07 


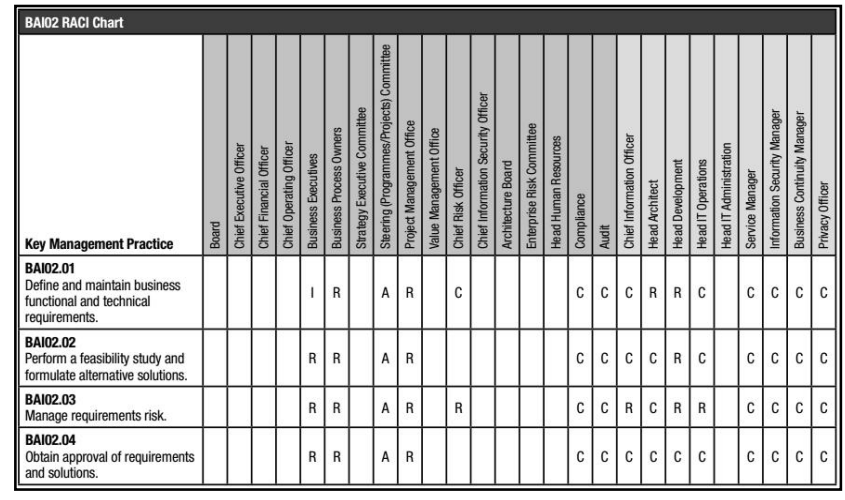

Gambar 5. RACI BAI02

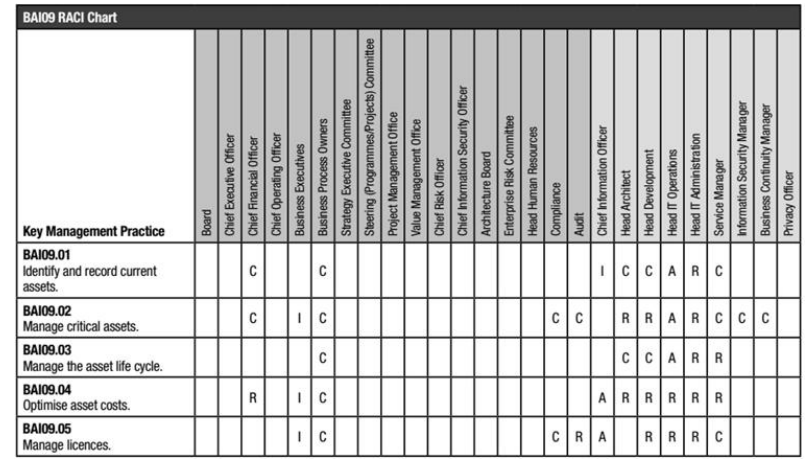

Gambar 6. RACI BAI09

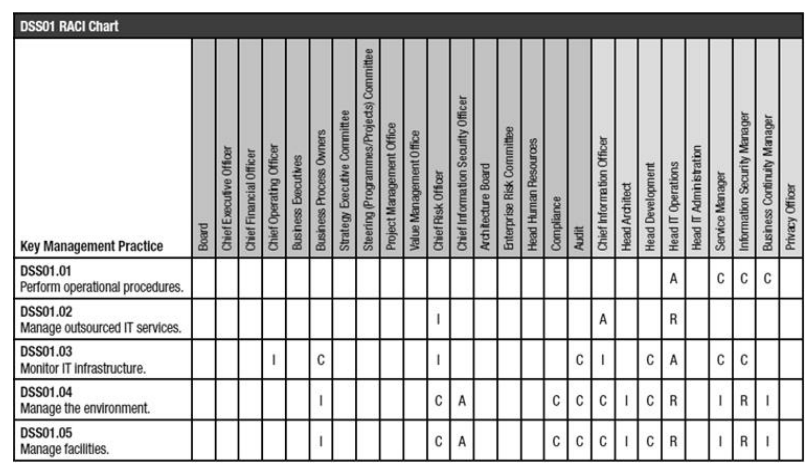

Gambar 7. RACI DSS01

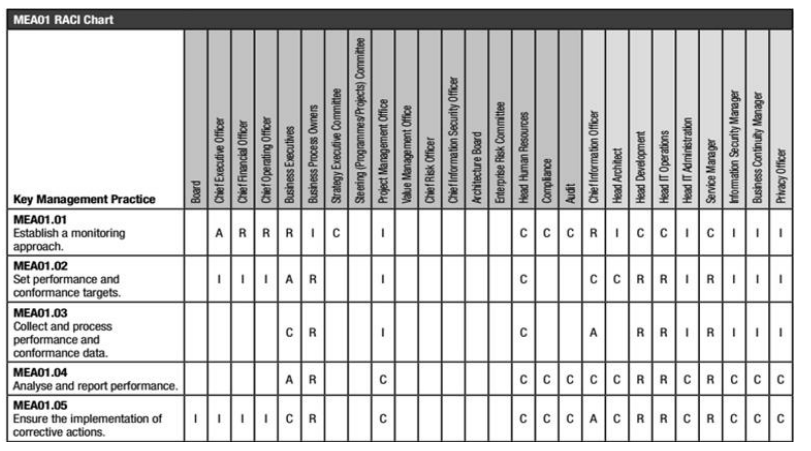

Gambar 8. RACI MEA 01

\section{HASIL DAN DISKUSI}

Perangkat Daerah pada sebuah Kota beragam jumlah dan kondisi Tata Kelolanya, karenanya pada penelitian ini kriteria Perangkat Daerah yang diteliti adalah Kecamatan yaitu Perangkat Daerah yang merupakan Representatif dari rata rata terhadap kondisi TI Perangkat Daerah pada umumnya di Kota.

Penilaian dilakukan sesuai dengan tahapan kegiatan. Pada bagian ini terdapat 3 point penting, yaitu nara sumber, indikator penilaian dan hasil penilaian:

\subsection{Narasumber}

Sebelum melaksanakan kunjungan lapangan, peneliti melakukan pemetaan terhadap narasumber dengan mempertimbangkan pengelompokan tupoksi jabatan pada Perangkat Daerah dan Penangung jawab aktivitas pada RACI.

TABEL 4. Pemetaan Narasumber Berdasarkan

RACI

\begin{tabular}{|c|l|c|l|c|}
\hline No & $\begin{array}{c}\text { Jabatan } \\
\text { Narasumber }\end{array}$ & Proses & Nama Proses & $\begin{array}{c}\text { Detail BP\&WP } \\
\text { Proses/Outcome } \\
\text { s }\end{array}$ \\
\hline 1. & $\begin{array}{l}\text { Kepala } \\
\text { Keuangan PD }\end{array}$ & APO06 & $\begin{array}{l}\text { Mengelola } \\
\text { Anggaran } \\
\text { dan Biaya }\end{array}$ & $\begin{array}{c}\text { APO06 01-03, } \\
\text { dan 05 } \\
01,02,04(\mathrm{O})\end{array}$ \\
\hline 2. & $\begin{array}{l}\text { Kepala Bidang } \\
\text { Informasi } \\
(\mathrm{CIO})\end{array}$ & APO06 & $\begin{array}{l}\text { Mengelola } \\
\text { Anggaran } \\
\text { dan Biaya }\end{array}$ & $\begin{array}{c}\text { APO06 04 } \\
03(\mathrm{O})\end{array}$ \\
\cline { 3 - 5 } & APO07 & $\begin{array}{l}\text { Mengelola } \\
\text { Sumber } \\
\text { Daya } \\
\text { Manusia }\end{array}$ & $\begin{array}{c}\text { APO07 01-02 } \\
(\mathrm{O})\end{array}$ \\
\cline { 3 - 5 } & & MEA0 & $\begin{array}{l}\text { Monitor, } \\
\text { Evaluasi, }\end{array}$ & $\begin{array}{c}\text { MEA01 01 } \\
(\mathrm{P})\end{array}$ \\
\hline 3. & $\begin{array}{l}\text { Kepala } \\
\text { Pengembanga } \\
\text { n TI }\end{array}$ & MEA0 & $\begin{array}{l}\text { Monitor, } \\
\text { Evaluasi, }\end{array}$ & $\begin{array}{c}\text { MEA01 02-05 } \\
(\mathrm{P})\end{array}$ \\
\hline 4. & $\begin{array}{l}\text { Kepala } \\
\text { Operasional TI }\end{array}$ & BAI09 & $\begin{array}{l}\text { Mengelola } \\
\text { Aset }\end{array}$ & $\begin{array}{c}\text { BAI09 01-02 } \\
(\mathrm{O})\end{array}$ \\
\cline { 3 - 5 } & & DSS01 & $\begin{array}{l}\text { Mengelola } \\
\text { Operasi }\end{array}$ & $\begin{array}{c}\text { DSS01 01-02 } \\
(\mathrm{O})\end{array}$ \\
\hline 5. & $\begin{array}{l}\text { Kepala Bagian } \\
\text { Pengelolaan } \\
\text { proyek }\end{array}$ & BAI02 & $\begin{array}{l}\text { Mengelola } \\
\text { Pendefinisia } \\
\text { n Kebutuhan }\end{array}$ & $\begin{array}{c}\text { BAI02 01-04 } \\
(\mathrm{O})\end{array}$ \\
\hline
\end{tabular}

\subsection{Indikator}

Dari hasil casding enabler goals kemudian dilakukan pemerioritasan kembali yang disesuaikan dengan kebutuhan permerintahan Kota sehingga diperoleh proses berikut.

\begin{tabular}{|l|l|}
\hline Kode Proses & \multicolumn{1}{|c|}{ Definisi } \\
\hline APO06 & Mengelola Anggaran dan Biaya \\
\hline APO07 & Mengelola Sumber Daya Manusia \\
\hline BAI02 & Mengelola Pendefinisian Kebutuhan \\
\hline BAI09 & Mengelola Aset \\
\hline DSS01 & Mengelola Operasi \\
\hline MEA01 & $\begin{array}{l}\text { Monitor, Evaluasi, Penilaian kinerja dan ukuran } \\
\text { kinerja }\end{array}$ \\
\hline
\end{tabular}

Berdasarkan PAM (Process Assessment Model) pada COBIT 5 terdapat indikator yaitu praktik dasar (base practices (BPs)) dan hasil kerja (work products(WPs)). Total Bps dan Wps pada 6 proses di atas adalah 161 indikator. 
Dari hasil umpan balik yang dilakukan terdapat beberapa Work Produk penempatannya disatukan pada dokumen pemerintahan, serta adanya indikator yang dikategorikan belum ada ditambah relevansi kebutuhan tata kelola sehingga daftar pertanyaan dapat disesuaikan menjadi 88 pertanyaan

\subsection{Hasil Penilaian}

Hasil nilai dibagi menjadi 2 bagian sesuai urutan, yaitu proses APO06, APO 07, dan BAI02 kemudian proses BAI 09, DSS01, dan MEA01.

TABEL 5. Hasil nilai proses APO06, APO07, dan BAI02

\begin{tabular}{|c|c|c|c|c|c|}
\hline \multicolumn{2}{|c|}{ APO 06} & \multicolumn{2}{|c|}{ APO 07} & \multicolumn{2}{|c|}{ BAI 02} \\
\hline $\begin{array}{c}\text { Number } \\
\text { Input/Output }\end{array}$ & Nilai & $\begin{array}{c}\text { Number } \\
\text { Input/Output }\end{array}$ & Nilai & $\begin{array}{c}\text { Number } \\
\text { Input/Output }\end{array}$ & Nilai \\
\hline $\begin{array}{l}\text { APO06-BP1- } \\
1\end{array}$ & $100 \%$ & $\begin{array}{l}\text { APO07-BP1- } \\
1\end{array}$ & $100 \%$ & BAI02-BP1 & $100 \%$ \\
\hline $\begin{array}{l}\text { APO06-BP1- } \\
2\end{array}$ & $100 \%$ & $\begin{array}{l}\text { APO07-BP1- } \\
2\end{array}$ & $100 \%$ & BAI02-BP4-1 & $0 \%$ \\
\hline APO06-BP3 & $0 \%$ & $\begin{array}{l}\text { APO07-BP2- } \\
1\end{array}$ & $0 \%$ & BAI02-BP4-2 & $100 \%$ \\
\hline $\begin{array}{l}\text { APO06-BP2- } \\
1\end{array}$ & $100 \%$ & $\begin{array}{l}\text { APO07-BP2- } \\
2\end{array}$ & $0 \%$ & BAI02-BP2-1 & $0 \%$ \\
\hline $\begin{array}{l}\text { APO06-BP2- } \\
2\end{array}$ & $100 \%$ & $\begin{array}{l}\text { APO07-BP5- } \\
1\end{array}$ & $100 \%$ & BAI02-BP2-2 & $0 \%$ \\
\hline APO06-BP4 & $100 \%$ & $\begin{array}{l}\text { APO07-BP5- } \\
2\end{array}$ & $100 \%$ & BAI02-BP3 & $0 \%$ \\
\hline $\begin{array}{l}\text { APO06-BP5- } \\
1\end{array}$ & $0 \%$ & $\begin{array}{l}\text { APO07-BP3- } \\
1\end{array}$ & $100 \%$ & $\begin{array}{l}\text { APO01- } \\
\text { WP15 }\end{array}$ & $0 \%$ \\
\hline $\begin{array}{l}\text { APO06-BP5- } \\
2\end{array}$ & $100 \%$ & $\begin{array}{l}\text { APO07-BP3- } \\
2\end{array}$ & $100 \%$ & APO03-WP2 & $0 \%$ \\
\hline BAI09-WP1 & $100 \%$ & $\begin{array}{l}\text { APO07-BP4- } \\
1\end{array}$ & $100 \%$ & $\begin{array}{l}\text { APO10- } \\
\text { WP11 }\end{array}$ & $0 \%$ \\
\hline APO06-WP1 & $0 \%$ & $\begin{array}{l}\text { APO07-BP4- } \\
2\end{array}$ & $100 \%$ & BAI01-WP17 & $0 \%$ \\
\hline APO06-WP2 & $0 \%$ & APO07-BP6 & $100 \%$ & BAI02-WP2 & $0 \%$ \\
\hline APO06-WP3 & $100 \%$ & EDM04-WP1 & $100 \%$ & APO10-WP2 & $0 \%$ \\
\hline APO06-WP4 & $0 \%$ & EDM04-WP3 & $100 \%$ & APO11-WP6 & $0 \%$ \\
\hline APO06-WP6 & $100 \%$ & EDM04-WP8 & $0 \%$ & BAI02-WP4 & $0 \%$ \\
\hline APO06-WP7 & $100 \%$ & APO01-WP9 & $0 \%$ & BAI02-WP5 & $0 \%$ \\
\hline APO06-WP8 & $100 \%$ & APO06-WP4 & $0 \%$ & BAI02-WP6 & $0 \%$ \\
\hline APO06-WP9 & $100 \%$ & APO06-WP5 & $100 \%$ & BAI02-WP7 & $0 \%$ \\
\hline $\begin{array}{l}\text { APO06- } \\
\text { WP10 }\end{array}$ & $100 \%$ & $\begin{array}{l}\text { Outside } \\
\text { COBIT }\end{array}$ & $100 \%$ & $\begin{array}{l}\text { APO01- } \\
\text { WP14 }\end{array}$ & $0 \%$ \\
\hline BAI01-WP6 & $100 \%$ & EDM01-WP5 & $100 \%$ & $\begin{array}{l}\text { APO01- } \\
\text { WP16 }\end{array}$ & $0 \%$ \\
\hline BAI01-WP10 & $100 \%$ & EDM04-WP8 & $100 \%$ & APO03-WP4 & $0 \%$ \\
\hline $\begin{array}{l}\text { APO06- } \\
\text { WP11 }\end{array}$ & $100 \%$ & BAI08-WP2 & $100 \%$ & APO03-WP6 & $0 \%$ \\
\hline $\begin{array}{l}\text { APO06- } \\
\text { WP12 } \\
\end{array}$ & $100 \%$ & BAI08-WP4 & $100 \%$ & $\begin{array}{l}\text { APO03- } \\
\text { WP12 }\end{array}$ & $0 \%$ \\
\hline $\begin{array}{l}\text { APO06- } \\
\text { WP13 }\end{array}$ & $100 \%$ & DSS04-WP14 & $100 \%$ & APO11-WP6 & $0 \%$ \\
\hline APO04-WP4 & $0 \%$ & DSS04-WP15 & $100 \%$ & $\begin{array}{l}\text { APO10- } \\
\text { WP12 }\end{array}$ & $0 \%$ \\
\hline APO05-WP7 & $0 \%$ & EDM01-WP5 & $100 \%$ & $\begin{array}{l}\text { APO10- } \\
\text { WP13 }\end{array}$ & $0 \%$ \\
\hline APO06-WP5 & $100 \%$ & APO04-WP9 & $0 \%$ & BAI02-WP1 & $0 \%$ \\
\hline EDM02-WP6 & $0 \%$ & BAI05-WP14 & $100 \%$ & BAI02-WP3 & $0 \%$ \\
\hline EDM02-WP5 & $0 \%$ & BAI05-WP7 & $0 \%$ & BAI02-WP8 & $0 \%$ \\
\hline \multirow[t]{6}{*}{28} & $81 \%$ & DSS06-WP6 & $100 \%$ & BAI02-WP9 & $0 \%$ \\
\hline & & EDM04-WP4 & $0 \%$ & & $17 \%$ \\
\hline & & EDM04-WP7 & $100 \%$ & & \\
\hline & & EDM04-WP1 & $100 \%$ & & \\
\hline & & EDM04-WP8 & $100 \%$ & & \\
\hline & & $\begin{array}{l}\text { APO01- } \\
\text { WP10 }\end{array}$ & $100 \%$ & & \\
\hline
\end{tabular}

\begin{tabular}{|c|c|} 
APO06-WP6 & $100 \%$ \\
\hline APO06-WP7 & $100 \%$ \\
\hline EDM01-WP6 & $0 \%$ \\
\hline EDM04-WP9 & $0 \%$ \\
\hline BAI08-WP6 & $0 \%$ \\
\hline DSS04-WP16 & $100 \%$ \\
\hline DSS04-WP17 & $100 \%$ \\
\hline EDM01-WP6 & $0 \%$ \\
\hline 42 & $74 \%$ \\
\hline
\end{tabular}

Adapun untuk nilai proses BAI09, DSS01, dan MEA01 terdapat pada tabel di bawah.

TABEL 6. Hasil nilai proses BAI09, DSS01, dan MEA01

\begin{tabular}{|c|c|c|c|c|c|}
\hline \multicolumn{2}{|c|}{ BAI 09} & \multicolumn{2}{|c|}{ DSS 01} & \multicolumn{2}{|c|}{ MEA01 } \\
\hline $\begin{array}{c}\text { Number } \\
\text { Input/Output }\end{array}$ & Nilai & $\begin{array}{c}\text { Number } \\
\text { Input/Output }\end{array}$ & Nilai & $\begin{array}{c}\text { Number } \\
\text { Input/Output }\end{array}$ & Nilai \\
\hline BAI09-BP5 & $0 \%$ & DSS01-BP1 & $100 \%$ & MEA01-BP1-1 & $0 \%$ \\
\hline BAI09-BP1 & $100 \%$ & DSS01-BP2 & $100 \%$ & MEA01-BP1-2 & $0 \%$ \\
\hline BAI09-BP2 & $100 \%$ & DSS01-BP3-1 & $100 \%$ & MEA01-BP2 & $100 \%$ \\
\hline BAI09-BP3 & $100 \%$ & DSS01-BP3-2 & $0 \%$ & MEA01-BP3-1 & $0 \%$ \\
\hline BAI09-BP4 & $100 \%$ & DSS01-BP4-1 & $100 \%$ & MEA01-BP3-2 & $100 \%$ \\
\hline BAI09-WP11 & $0 \%$ & DSS01-BP4-2 & $100 \%$ & MEA01-BP5 & $100 \%$ \\
\hline BAI09-WP12 & $0 \%$ & DSS01-BP5 & $100 \%$ & MEA01 - BP4 & $0 \%$ \\
\hline BAI10-WP3 & $100 \%$ & BAI05-WP10 & $100 \%$ & EDM05-WP5 & $0 \%$ \\
\hline BAI09-WP2 & $100 \%$ & APO09-WP6 & $0 \%$ & EDM05-WP1 & $100 \%$ \\
\hline BAI09-WP4 & $0 \%$ & DSS01-WP2 & $100 \%$ & EDM05-WP2 & $100 \%$ \\
\hline BAI09-WP5 & $0 \%$ & DSS01-WP5 & $0 \%$ & MEA01-WP1 & $0 \%$ \\
\hline BAI03-WP5 & $100 \%$ & DSS01-WP7 & $100 \%$ & MEA01-WP2 & $0 \%$ \\
\hline BAI09-WP1 & $100 \%$ & DSS01-WP8 & $0 \%$ & MEA01-WP3 & $100 \%$ \\
\hline BAI09-WP3 & $0 \%$ & DSS01-WP9 & $100 \%$ & APO09-WP8 & $0 \%$ \\
\hline BAI09-WP6 & $0 \%$ & 14 & $78 \%$ & APO10-WP10 & $0 \%$ \\
\hline BAI09-WP7 & $0 \%$ & & & BAI04-WP5 & $0 \%$ \\
\hline BAI09-WP8 & $0 \%$ & & & BAI05-WP11 & $100 \%$ \\
\hline BAI09-WP9 & $0 \%$ & & & BAI01-WP12 & $0 \%$ \\
\hline BAI09-WP10 & $0 \%$ & & & DSS02-WP13 & $0 \%$ \\
\hline \multirow[t]{9}{*}{19} & $33 \%$ & & & DSS01-WP8 & $0 \%$ \\
\hline & & & & MEA01-WP4 & $0 \%$ \\
\hline & & & & EDM05-WP4 & $0 \%$ \\
\hline & & & & APO01-WP2 & $0 \%$ \\
\hline & & & & APO01-WP12 & $100 \%$ \\
\hline & & & & MEA01-WP6 & $0 \%$ \\
\hline & & & & MEA01-WP7 & $0 \%$ \\
\hline & & & & MEA01-WP5 & $0 \%$ \\
\hline & & & & 29 & $41 \%$ \\
\hline
\end{tabular}

Pada penilaia tata kelola TI menurut PAM, untuk dapat naik ke level berikutnya harus bernilai Fully 
achieved (F) yaitu mencapai $\geq 85 \%$, sedangkan hasil yang diperoleh belum mencapai nilai minimum untuk dapat naik ke level 2.

Berikut adalah rekapitulasi hasil nilai kapabilitas tata kelola TI pada setiap proses.

TABEL 7. Rekapitulasi nilai tata kelola TI

\begin{tabular}{|c|c|c|c|c|c|}
\hline No & Proses & Deskripsi & $\begin{array}{l}\text { Rating } \\
\text { By } \\
\text { Criteria }\end{array}$ & $\begin{array}{l}\text { Rating } \\
\text { Levels }\end{array}$ & $\begin{array}{c}\text { Capability } \\
\text { Level } \\
\text { Achieved }\end{array}$ \\
\hline 1 & APO06 & $\begin{array}{l}\text { Mengelola } \\
\text { Anggaran } \\
\text { dan Biaya } \\
\end{array}$ & $81 \%$ & $\mathrm{~L}$ & 1 \\
\hline 2 & APO07 & $\begin{array}{l}\text { Mengelola } \\
\text { Sumber } \\
\text { Daya } \\
\text { Manusia }\end{array}$ & $74 \%$ & $\mathrm{~L}$ & 1 \\
\hline 3 & BAI02 & $\begin{array}{l}\text { Mengelola } \\
\text { Pendefinisian } \\
\text { Kebutuhan }\end{array}$ & $11 \%$ & $\mathrm{~N}$ & 0 \\
\hline 4 & BAI09 & $\begin{array}{l}\text { Mengelola } \\
\text { Aset }\end{array}$ & $33 \%$ & $\mathrm{P}$ & 1 \\
\hline 5 & DSS01 & $\begin{array}{l}\text { Mengelola } \\
\text { Operasi }\end{array}$ & $78 \%$ & $\mathrm{~L}$ & 1 \\
\hline 6 & MEA01 & $\begin{array}{l}\text { Monitor, } \\
\text { Evaluasi, } \\
\text { Penilaian } \\
\text { kinerja dan } \\
\text { ukuran } \\
\text { kinerja }\end{array}$ & $41 \%$ & $\mathrm{P}$ & 1 \\
\hline
\end{tabular}

\section{KESIMPULAN}

Kecenderungan hasil nilai tata kelola Perangkat Daerah adalah dapat mencapai level 1, dengan kesimpulan sebagai berikut:

1. Penilaian kondisi eksisting tata kelola teknologi informasi menggunakan best practice COBIT 5 yaitu Indikator Penilaian dan Narasumber disesuaikan dengan PAM (Process Assessment Model).

2. Hasil penilaian menunjukkan masih berada di level 1 dengan Nilai kematangan terendah pada proses BAI02 (Mengelola Pendefinisian Kebutuhan) yaitu $11 \%$, artinya untuk kematangan Tata kelola
TIK dalam Mengelola Sumber Daya Manusia, Mengelola Pendefinisian Kebutuhan, Mengelola Aset, Mengelola Operasi dan Monitor, Evaluasi, Penilaian kinerja dan ukuran kinerja mencapai tujuan proses. Umumnya praktik - praktik dasar sudah dilakukan tetapi tidak memiliki bukti berupa dokumen pendukung.

\section{UCAPAN TERIMAKASIH}

Terima kasih yang sebesar-besarnya kepada Pemerintah Kota dan Perangkat Daerah yang telah serta Lembaga Penelitian UNLA yang telah membantu pelaksanaan penelitian ini.

\section{DAFTAR PUSTAKA}

[1] ISACA, 2012, COBIT 5 for Information Security, ISACA, United States of America.

[2] Aisyah Nuraeni, KM Syarif Haryana, 2016, Penilaian Tata kelola Teknologi Informasi Dengan Menambahkan Unsur Keamanan Menggunakan Framework COBIT 5 pada Domain DSS, Jurnal Computech \& Bisnis, Bandung, Jawa Barat, Indonesia.

[3] Richardus E. Indrajit, 2014, Manajemen Organisasi dan Tata Kelola Teknologi Informasi, Aptikom, Jakarta.

[4] Schindlwick. Helmut (2017). IT Governance: How to Reduce Costs and Improve Data Quality through the Implementation of IT Governance 1st. USA.

[5] ISACA. 2012. COBIT 5: Enabling Processes. ISACA. United States of America.

[6] ISACA. 2012. COBIT 5: Process Assessment Model. ISACA. United States of America. 